\title{
Factors associated to the sleep quality of medical students
}

\author{
Fatores associados a qualidade do sono de \\ estudantes de medicina \\ Factores asociados a la calidad del sueño de \\ estudiantes de medicina
}

\author{
Solange Campos Vicentini ${ }^{1}$, Eliane Dantas Rocha ${ }^{2}$, Andrea dos Santos \\ Garcia ${ }^{3}$, André Luis do Nascimento Ferreira ${ }^{4}$, Hugo Macedo Ramos 5 , \\ Thiago Louro Quinellato6, Marcus Vinicius Gemelli Minucci, Luiz \\ Carlos Santiago ${ }^{8}$, Maria Tereza Serrano Barbosa ${ }^{9}$, \\ Carlos Roberto Lyra da Silva ${ }^{10}$
}

\begin{abstract}
1.Doutoranda, Programa de Pós Graduação em Enfermagem e Biociências (PPGENFBIO). Docente no Departamento de Ciências Fisiológicas (DCF), Universidade Federal do Estado do Rio de Janeiro (UNIRIO). Rio de Janeiro-RJ, Brasil. ORCID: https://orcid.org/0000-0002-4202-7514

2.Doutora, Departamento de Ciências Fisiológicas (DCF), Universidade Federal do Estado do Rio de Janeiro (UNIRIO). Rio de Janeiro-RJ, Brasil. ORCID: https://orcid.org/0000-0002-6371-3409

3.Doutoranda, Programa de Pós Graduação em Enfermagem e Biociências (PPGENFBIO). Universidade Federal do Estados do Rio de Janeiro (UNIRIO). Rio de Janeiro-RJ, Brasil. ORCID: https://orcid.org/00000002-2125-1437

4.Graduando da Escola de Medicina e Cirurgia (EMC), Universidade Federal do Estado do Rio de Janeiro (UNIRIO). Rio de Janeiro-RJ, Brasil. ORCID: https://orcid.org/0000-0002-6979-3075

5.Doutor, Laboratório de Fisiologia e Fisiopatologia Translacional, Faculdade de Medicina de Teresópolis, Centro Universitário Serra dos Órgãos (UNIFESO). Departamento de Fisiologia e Fisiopatologia, Faculdade de Medicina de Petrópolis (UNIFASE). Petrópolis-RJ, Brasil. ORCID: https://orcid.org/0000-0001-9098$\underline{8005}$

6.Doutor, Universidade Federal Fluminense (UFF). Rio das Ostras-RJ, Brasil. ORCID: https://orcid.org/0000-0001-8371-628X

7.Doutor, Departamento de Ciências Fisiológicas (DCF), Universidade Federal do Estado do Rio de Janeiro (UNIRIO), Rio de Janeiro-RJ, Brasil. ORCID: https://orcid.org/0000-0002-9462-4564

8.Doutor, Escola de Enfermagem Alfredo Pinto (EEAP). Universidade Federal do Estado do Rio de Janeiro (UNIRIO). Rio de Janeiro-RJ, Brasil. ORCID: https://orcid.org/0000-0002-9725-4626

9.Doutora, Departamento de Matemática Universidade Federal do Estado do Rio de Janeiro (UNIRIO). Rio de Janeiro-RJ, Brasil. ORCID: https://orcid.org/0000-0003-0977-5921

10.Doutor, Departamento de Enfermagem Fundamental, Escola de Enfermagem Alfredo Pinto (EEAP), Universidade Federal do Estado do Rio de Janeiro (UNIRIO). Rio de Janeiro-RJ, Brasil. ORCID: https://orcid.org/0000-0002-4327-6272
\end{abstract}

\section{Resumo}

Objetivo. Identificar os fatores associados a qualidade do sono dos estudantes de medicina a partir dos índices subjetivos de Pittsburgh e Epworth. Método. Estudo de natureza observacional e analítica, amostra constituída por 131 estudantes que preencheram o formulário, o questionário índice de Qualidade do Sono de Pittsburgh (PSQI) e a escala de Sonolência de Epworth (ESE). As associações entre a qualidade do sono e as variáveis qualitativas foram analisadas a partir do teste Qui-quadrado. Resultados. Verificou-se que $60,31 \%$ (ESE) dos participantes exibiram distúrbios de sonolência diurna e 73,28\% (PSQI) má qualidade. Conclusão. Os resultados demonstraram a necessidade da realização de um programa educativo entre os estudantes com vistas a melhoria da qualidade do sono e prevenção de agravos à saúde.

Unitermos. Sono; Estudantes de medicina; Transtornos do sono-vigília 


\begin{abstract}
Objective. To identify the factors associated with the sleep quality of medical students through the subjective indices of Pittsburg and Epworth. Method. It is an observational and analytical study, a sample consisting of 131 students who completed the form, the Pittsburgh Sleep Quality Index questionnaire (PSQI), and the Epworth Sleepiness Scale (ESS). Chi-square test to analyze possible associations between sleep quality and qualitative variables. Results. It found that $60.31 \%$ (ESS) of the participants presented daytime sleepiness disorders and $73.28 \%$ (PSQI) poor quality disorders. Conclusions. The results demonstrated the need to carry out an educational program among students to improve sleep quality and prevent health issues.
\end{abstract}

Keywords. Sleep; Medical Students; Sleep Wake Disorders

\title{
Resumen
}

Objetivo. Identificar los factores asociados con la calidad del sueño de los estudiantes de medicina a partir de los índices subjetivos de Pittsburgh y Epworth. Método. estudio observacional y analítico, muestra compuesta por 131 estudiantes que completaron el formulario, el cuestionario Pittsburgh Sleep Quality Index (PSQI) y la Epworth Sleepiness Scale (ESE). Las asociaciones entre la calidad del sueño y las variables cualitativas se analizaron mediante la prueba de chi-cuadrado. Resultados. Se encontró que el $60,31 \%$ (ESS) de los participantes presentaba trastornos de somnolencia diurna y el $73,28 \%$ (PSQI) presentaba mala calidad. Conclusión. Los resultados demuestran la necesidad de realizar un programa educativo entre los estudiantes con miras a mejorar la calidad del sueño y prevenir problemas de salud.

Palabras clave. Sueño; Estudiantes de medicina; Trastornos del sueño-vigilia

Research developed at Universidade Federal do Estado do Rio de Janeiro (UNIRIO). Rio de Janeiro-RJ, Brasil.

\section{INTRODUCTION}

Sleep is a fundamental biological function for the wellbeing and good functioning of the human organism ${ }^{1}$. Changes in sleep stages can trigger significant disturbances in body metabolism, unpredictable lapses in attention, and decreased performance in daily activities ${ }^{2,3}$.

Sociodemographic and pathophysiological factors, such as age, sex, smoking, excessive alcohol consumption, use of drugs, irregular lifestyle, as well as a reduction in the number of sleep hours, can cause stress and sleep deprivation, in 
addition to excessive daytime sleepiness, significantly compromising the quality of life of individuals ${ }^{3}$.

Studies have shown that the behavior adopted by Brazilian university students, such as irregular sleep time, prolonged naps during daytime, use of alcohol before bed, studying or accessing the internet in bed, everyday habits in this population, classified them as bad sleepers, making them prone to disruption of the circadian cycle and deterioration of sleep quality ${ }^{3-5}$.

Among medical students, it has been found that they often consider sleep quality being secondary in the context of fulfilling their academic activities, which do not allow them to sleep properly ${ }^{6,7}$. One study identified insufficient sleep and sleep disorders as complaints common among these undergraduates, which can result in negative impacts on their cognitive, physical, and mental performance ${ }^{8}$. The analysis of the sleep of medical students from Saudi Arabia showed a close relationship between insufficient sleep of these individuals and high scores for depression, anxiety, and stress ${ }^{9}$. Thus, both studies emphasized the close relationship between quality sleep and the well-being of these students.

Medical students have a rigorous demand for studies, a full-time curricular load, extracurricular activities that, added to the lack of time for family and social activities and the stress of good academic performance, make them vulnerable to sleep disorders ${ }^{10,11}$. 
Hence, medical students' sleep has been subjectively assessed through standardized research instruments developed to analyze the quality of sleep (the Pittsburgh Sleep Quality Index - PSQI) and daytime sleepiness (the Epworth Sleepiness Scale - ESS) ${ }^{12,13}$.

For these reasons, it is important that more studies address adequate sleep-wake patterns aiming at the wellbeing, comfort, healthy academic performance, and quality of life of these future health professionals.

The objective was to identify the factors associated with the sleep quality of medical students from the subjective indices of PSQI and ESS.

\section{METHOD}

\section{Sample}

Here is an observational and analytical study with a quantitative approach. The target population of this research consisted of 813 medical students between the first and the tenth semesters in 2019. As inclusion criteria, all students regularly enrolled, from the first to the tenth semesters in the medical course of a public university in Rio de Janeiro, aged 18 years or over, who signed the free and informed consent form. Students from the last two semesters were excluded due to anticipation of graduation. Thus, 131 participants were eligible for the study.

The Research Ethics Committee of the Federal University of the State of Rio de Janeiro approved the study 
(CAAE: 04956818.0.0000.5285. Opinion: 3,168,630), meeting the requirements of resolution 466/2012.

\section{Procedure}

Data collection befell from May to November 2019. The instruments used for data collection were:

1. Individual identification form with demographic and behavioral information: gender, age group, semester enrolled, means of transport from university to home, time to return home from university, practice of physical exercise, smoking, alcoholism, if they had a chronic disease, use of pharmacological therapy or not for sleep disorders, use of medication that interferes with sleep.

2. Pittsburgh Sleep Quality Index (PSQI) - evaluates the subjective quality of sleep in the last 30 days. Validated and tested in Brazil, it consists of 19 self-filling questions about sleep habits. The questions are clustered into seven components with equal weighting and a scale ranging from 0 , indicating no occurrences, to 3 , indicating many. The final score ranges from 0 to 21 points. Scores $\leq 4$ indicate good sleep quality, 5 to 10 poor quality of sleep, and $>10$ presence of sleep disorder-11.

3. Epworth Sleepiness Scale (ESS) - the scale assesses excessive daytime sleepiness (EDS). Translated and validated for use in Brazil, the questions evaluate the possibility of sleeping in eight everyday situations that vary according to the activity and the environment. The score is the sum of the eight items and varies from 0 to 24. A score 
below 10 means no sleepiness, and above 10 is considered pathological ${ }^{4}$.

The questionnaires and the individual identification form were entered on tablets (Samsung Galaxy Tab E SMT113NU TAE 7PR, www.samsung.com.br wi-fi 8GB), and the answers were accessed through the Kobotoolbox software ${ }^{14}$.

A mechanical scale with an anthropometric ruler (Classic Mechanical Scale $150 \mathrm{~kg}$-Welmy-110CH, SP, $100 \mathrm{~g}$ divisions) was used to obtain the weight and height of students to calculate the body mass index (BMI) and an anthropometric tape (TR4013-SANNY $®$ ) with a precision of $0.1 \mathrm{~cm}$ and a maximum field of $150 \mathrm{~cm}$ for the measurements of the abdominal and neck circumferences.

\section{Statistical analysis}

The data collected by the different instruments were organized in a MS Excel spreadsheet and the analysis was carried out online using the open access statistical program $\mathrm{R}$ version 64.4.0.3, using the Rcommander version 2.7.0 package.

In the statistical analysis, the chi-square test evaluated the associations between sociodemographic and anthropometric variables with the classification of the ESS and PSQI. The level of significance chosen was $5 \%(p<0.05)$.

\section{RESULTS}

The sample consisted of 131 students $(16.11 \%$ of the target population) who agreed to participate in the study. 
The data presented in Table 1 show that $79(60.31 \%)$ were female, 119 (90.84\%) were in the age group of $18-25$ and $102(77.8 \%)$ were between the first and the fourth semesters.

It was found that $68(51.91 \%)$ practiced physical exercise regularly, 99 (75.57\%) used public transportation, and $80(61.07 \%)$ spent more than 30 minutes getting home. It was noticed that $126(96.18 \%)$ were not smokers, 75 (57.25\%) consumed alcohol. Only $10(7.63 \%)$ reported resorting to any sleep treatment, $56(42.75 \%)$ used some medication that could interfere with sleep, and 40 (30,53\%) reported having a chronic disease.

Table 2 represents the anthropometric characteristics regarding the physical conditions associated with risks for the development of health problems among students. The BMI of $42(32.06 \%)$ students presented values that classified them as obese. The neck circumference of 37 (28.24) and the abdominal circumference of $24(18.32 \%)$ had increased values.

The results of the subjective sleep assessment analyzed using the ESS and PSQI scales are shown in Table 3. On the ESS $79(60.31 \%)$ students had EDS and on the PSQI 96 (73.28\%) were classified as having poor sleep quality.

Among EDS patients $(60.31 \%)$, most students were female $(69.6 \%)$ and $46.2 \%$ male. 
Table 1. Profile of medical students.

\begin{tabular}{|c|c|c|}
\hline CATEGORIES & PARTICIPANTS & $\%$ \\
\hline \multicolumn{3}{|l|}{ Gender } \\
\hline Female & 79 & 61.31 \\
\hline Male & 52 & 39.69 \\
\hline \multicolumn{3}{|l|}{ Semester } \\
\hline First & 44 & 33.59 \\
\hline Second & 26 & 19.85 \\
\hline Third & 16 & 12.21 \\
\hline Fourth & 16 & 12.21 \\
\hline Ninth & 12 & 9.16 \\
\hline Tenth & 17 & 12.98 \\
\hline \multicolumn{3}{|l|}{ Age range } \\
\hline $18-25$ & 119 & 90.84 \\
\hline $26-45$ & 12 & 9.16 \\
\hline \multicolumn{3}{|l|}{ Physical Exercise } \\
\hline Yes & 68 & 51.91 \\
\hline No & 63 & 48.09 \\
\hline \multicolumn{3}{|l|}{ Transportation } \\
\hline Public & 99 & 75.57 \\
\hline Private & 32 & 24.43 \\
\hline \multicolumn{3}{|l|}{ Time spent } \\
\hline$<30$ & 51 & 38.93 \\
\hline$>30$ & 80 & 61.07 \\
\hline \multicolumn{3}{|l|}{ Smoking } \\
\hline Yes & 5 & 3.82 \\
\hline No & 126 & 96.18 \\
\hline \multicolumn{3}{|c|}{ Alcohol consumption } \\
\hline Yes & 75 & 57.25 \\
\hline No & 56 & 42.75 \\
\hline \multicolumn{3}{|l|}{ Medication } \\
\hline Yes & 56 & 42.75 \\
\hline No & 75 & 57.25 \\
\hline \multicolumn{3}{|l|}{ Chronic disease } \\
\hline Yes & 40 & 30.53 \\
\hline No & 91 & 69.47 \\
\hline \multicolumn{3}{|l|}{ Sleep treatment } \\
\hline Yes & 10 & 7.63 \\
\hline No & 121 & 92.37 \\
\hline Total & 131 & 100 \\
\hline
\end{tabular}

Table 2. Anthropometric profile of medical students.

\begin{tabular}{lcc}
\hline \multicolumn{1}{c}{ Categories } & $\mathbf{N}$ & \% \\
\hline Body Mass Index (BMI) & & 67.94 \\
$*$ Normal & 89 & 32.06 \\
$* *$ Obese & 42 & 71.76 \\
Neck Circumference (NC) & & 28.24 \\
$*$ Normal & 94 & \\
$* *$ Elevated & 37 & 81.68 \\
Abdominal Circumference (AC) & & 18.32 \\
$*$ Normal & 107 & 100 \\
$* *$ Elevated & 24 & \\
Total & 131 & \\
\hline
\end{tabular}

Scores: BMI: $*<26 / * * \geq 26$

NC: *Female $\leq 34 \mathrm{~cm} / * *$ Female $>34 \mathrm{~cm}$ and $*$ Male $\leq 37 \mathrm{~cm} / * *$ Male $>37 \mathrm{~cm}$

AC: *Female $\leq 80 \mathrm{~cm} / * *$ Female $>80 \mathrm{~cm}$ and $*$ Male $\leq 94 \mathrm{~cm} / * *$ Male $>94 \mathrm{~cm}$ 
Table 3. Epworth Sleepiness Scale and Pittsburgh Sleep Quality Index of medical students.

\begin{tabular}{lcc}
\hline \multicolumn{1}{c}{ Categories } & Participants & $\mathbf{\%}$ \\
\hline Epworth Sleepiness Scale (ESS) & 79 & 60.31 \\
$*$ Yes & 52 & 39.69 \\
**No & & 73.28 \\
$\begin{array}{l}\text { Pittsburgh Sleep Quality Index (PSQI) } \\
\text { *Poor quality }\end{array}$ & 96 & 26.72 \\
**Good quality & 35 & 100 \\
Total & 131 & \\
\hline Scores: ESS: $\geq 10 / * *<10 \quad$ PSQI: * $\geq 5 / * * 4$ & &
\end{tabular}

In students with chronic diseases $67.5 \%$ had this sleep disorder, while in those without illnesses, only $42.9 \%$ had EDS. Both among genders and in patients with chronic disease, these differences were significant.

On returning home, $66.2 \%$ of students who spent more than 30 minutes and $51 \%$ of those who took less time to arrive had EDS. Among students aged 26-45, 83.3\% had EDS. The same was true for only $58 \%$ among those aged $18-$ 25 . Regarding neck circumference, $75 \%$ of students who had increased values and $57 \%$ of those who had normal measures exhibited EDS. The differences found were not significant (Table 4).

In the assessment of sleep quality through the PSQI, $73.28 \%$ of the participants had a poor-quality classification. Regarding the use of alcoholic beverages, $80 \%$ of students who reported consuming alcohol and $64.3 \%$ of those who did not consume it slept with poor quality. 
Table 4. Association between sociodemographic and anthropometric categories with the Epworth Excessive Daytime Sleepiness scale.

\begin{tabular}{|c|c|c|c|c|c|}
\hline \multicolumn{6}{|c|}{ EXCESSIVE DAYTIME SLEEPINESS } \\
\hline Categories & YES & $\%$ & NO & $\%$ & * P-value \\
\hline Gender & & & & & 0.01 \\
\hline Female & 55 & 69.6 & 24 & 30.4 & \\
\hline Male & 24 & 46.2 & 28 & 53.8 & \\
\hline Semester & & & & & 0.72 \\
\hline First & 27 & 61.4 & 17 & 38.6 & \\
\hline Second & 13 & 50.0 & 13 & 50.0 & \\
\hline Third & 9 & 56.2 & 7 & 43.8 & \\
\hline Fourth & 12 & 75.0 & 4 & 25.0 & \\
\hline Ninth & 7 & 58.3 & 5 & 41.7 & \\
\hline Tenth & 11 & 64.7 & 6 & 35.3 & \\
\hline Age range & & & & & 0.09 \\
\hline $18-25$ & 69 & 58.0 & 50 & 42.0 & \\
\hline $26-45$ & 10 & 83.3 & 2 & 16.7 & \\
\hline $\begin{array}{l}\text { Physical } \\
\text { exercise }\end{array}$ & & & & & 0.15 \\
\hline Yes & 37 & 54.4 & 31 & 45.6 & \\
\hline No & 42 & 66.7 & 21 & 33.3 & \\
\hline Transport & & & & & 0.77 \\
\hline Public & 59 & 59.6 & 40 & 40.4 & \\
\hline Private & 20 & 62.5 & 12 & 37.5 & \\
\hline Time spent & & & & & 0.08 \\
\hline$<30$ & 26 & 51.0 & 25 & 49.0 & \\
\hline$>30$ & 53 & 66.2 & 27 & 33.8 & \\
\hline Smoking & & & & & 0.34 \\
\hline Yes & 2 & 40 & 3 & 60 & \\
\hline No & 77 & 61.1 & 49 & 38.9 & \\
\hline $\begin{array}{c}\text { Alcohol } \\
\text { consumption }\end{array}$ & & & & & 0.66 \\
\hline Yes & 44 & 58.7 & 31 & 41.3 & \\
\hline No & 35 & 62.5 & 21 & 37.5 & \\
\hline Medication & & & & & 0.13 \\
\hline Yes & 38 & 67.9 & 18 & 32.1 & \\
\hline No & 41 & 54.7 & 34 & 55.3 & \\
\hline $\begin{array}{l}\text { Chronic } \\
\text { disease }\end{array}$ & & & & & 0.01 \\
\hline Yes & 27 & 67.5 & 13 & 32.5 & \\
\hline No & 52 & 42.9 & 52 & 57.1 & \\
\hline $\begin{array}{c}\text { Sleep } \\
\text { treatment }\end{array}$ & & & & & 0.51 \\
\hline Yes & 7 & 70.0 & 3 & 30.0 & \\
\hline No & 72 & 59.5 & 49 & 40.5 & \\
\hline Bmi class & & & & & 0.79 \\
\hline Normal & 53 & 59.6 & 36 & 40.4 & \\
\hline Obese & 26 & 61.9 & 16 & 38.1 & \\
\hline Nc class & & & & & 0.36 \\
\hline Normal & 59 & 62.8 & 35 & 37.2 & \\
\hline Elevated & 20 & 54.1 & 17 & 45.9 & \\
\hline Ac class & & & & & 0.10 \\
\hline Normal & 61 & 57.0 & 46 & 43.0 & \\
\hline Elevated & 18 & 75.0 & 6 & 25.0 & \\
\hline Total & 79 & & 52 & & \\
\hline
\end{tabular}


Regarding the use of medication that could interfere with sleep, $78.6 \%$ of the students who reported using some medication and $48.9 \%$ of those who did not use these drugs presented poor sleep quality. In both cases, the differences were significant.

Table 5 shows that $82.4 \%$ of students who took less than 30 minutes and $67.5 \%$ of those who spent more time getting home had poor sleep quality. In the analysis of the body mass index, $81 \%$ of students classified as obese and $67.5 \%$ of students with a normal index exhibited poor sleep quality. There were no significant differences.

\section{DISCUSSION}

For some years, excessive daytime sleepiness and poor sleep quality have been increasingly reported in the university population due to its high prevalence ${ }^{15}$. In this study, most participants (60.31\%) had scores considered pathological for daytime sleepiness, with a predominance of females $(69.6 \%)$, corroborating the study of EDS in university students, with prevalence ranging between 24\% and $39 \%$. In the sample, $36.3 \%$ had EDS, the majority being women ${ }^{15}$. Although the results can be alarming, it is noteworthy that they are inferior to other studies.

Another study points out that these students represent a population prone to sleep-related issues because they have inadequate sleep habits, as a rule, caused by excessive activities $^{16}$. 
Table 5. Association between sociodemographic and anthropometric categories with the Pittsburgh Sleep Quality Index.

\begin{tabular}{|c|c|c|c|c|c|}
\hline \multicolumn{6}{|c|}{ PITTSBURGH SLEEP QUALITY INDEX } \\
\hline Categories & POOR & $\%$ & GOOD & $\%$ & *P-value \\
\hline Gender & & & & & 0.20 \\
\hline Female & 61 & 77.2 & 18 & 22.8 & \\
\hline Male & 35 & 67.3 & 17 & 32.7 & \\
\hline Semester & & & & & 0.78 \\
\hline First & 32 & 72.7 & 12 & 27.3 & \\
\hline Second & 19 & 73.1 & 7 & 26.9 & \\
\hline Third & 10 & 62.5 & 6 & 37.5 & \\
\hline Fourth & 13 & 81.2 & 3 & 18.8 & \\
\hline Ninth & 8 & 66.7 & 4 & 33.3 & \\
\hline Tenth & 14 & 82.4 & 3 & 17.6 & \\
\hline Age range & & & & & 0.88 \\
\hline $18-25$ & 87 & 73.1 & 32 & 36.9 & \\
\hline $26-45$ & 9 & 75.0 & 3 & 25.0 & \\
\hline $\begin{array}{l}\text { Physical } \\
\text { exercise }\end{array}$ & & & & & 0.94 \\
\hline Yes & 50 & 73.5 & 18 & 26.5 & \\
\hline No & 46 & 73.0 & 17 & 27.0 & \\
\hline Transport & & & & & 0.47 \\
\hline Public & 71 & 71.7 & 28 & 29.3 & \\
\hline Private & 25 & 78.1 & 7 & 21.9 & \\
\hline Time spent & & & & & 0.06 \\
\hline$<30$ & 42 & 82.4 & 9 & 17.6 & \\
\hline$>30$ & 54 & 67.5 & 26 & 32.5 & \\
\hline Smoking & & & & & 0.72 \\
\hline Yes & 4 & 80.0 & 1 & 20.0 & \\
\hline No & 92 & 73.0 & 34 & 27.0 & \\
\hline $\begin{array}{c}\text { Alcohol } \\
\text { consumption }\end{array}$ & & & & & 0.04 \\
\hline Yes & 60 & 80.0 & 27 & 20.0 & \\
\hline No & 36 & 64.3 & 8 & 35.7 & \\
\hline Medication & & & & & 0.02 \\
\hline Yes & 44 & 78.6 & 12 & 21.4 & \\
\hline No & 52 & 48.9 & 23 & 51.1 & \\
\hline $\begin{array}{l}\text { Chronic } \\
\text { disease }\end{array}$ & & & & & 0.89 \\
\hline Yes & 29 & 72.5 & 11 & 37.5 & \\
\hline No & 67 & 73.6 & 24 & 26.4 & \\
\hline $\begin{array}{c}\text { Sleep } \\
\text { treatment }\end{array}$ & & & & & 0.21 \\
\hline Yes & 9 & 90.0 & 1 & 10.0 & \\
\hline No & 87 & 71.9 & 34 & 28.1 & \\
\hline Bmi class & & & & & 0.17 \\
\hline Normal & 62 & 69.7 & 27 & 30.3 & \\
\hline Obese & 34 & 81.0 & 8 & 19.0 & \\
\hline Nc class & & & & & 0.96 \\
\hline Normal & 69 & 73.4 & 25 & 26.6 & \\
\hline Elevated & 27 & 73.0 & 10 & 27.0 & \\
\hline Ac class & & & & & 0.47 \\
\hline Normal & 77 & 72.0 & 30 & 28.0 & \\
\hline Elevated & 19 & 79.2 & 5 & 20.8 & \\
\hline Total & 96 & & 35 & & \\
\hline
\end{tabular}


A study conducted with 800 medical students from various institutions in Brazil, $48.1 \%$ had scores considered pathological, and $10.3 \%$ considered severe for daytime sleepiness ${ }^{17}$. Results of a meta-analysis showed the prevalence of EDS in $46.1 \%$ of medical students and poor sleep quality in $51.5 \%$ of students ${ }^{18}$.

Exogenous and/or endogenous factors can cause EDS and, in this study, $66.2 \%$ of the students who spent more time returning home from the university and $59.6 \%$ who used public transport had high scores for the EDS, which could lead to a reduction in nighttime sleep so they could attend academic classes, extracurricular and family demands.

In Taiwan, 35\% of people who entered nursing school had EDS. The author attributed latency and subjective sleep quality, assessed in the study, as possible causes. For the author, the short duration of nocturnal sleep and irregularities in the sleep-wake cycle increase the vulnerability of these students to develop EDS ${ }^{19}$.

In this research, $61.9 \%$ of students classified as obese and $75 \%$ of those who had increased waist circumference measurements exhibited EDS, confirmed by results found in Nutrition students in Chile in a study whose author established an association between fewer hours of sleep and risk of obesity. The author warns of short sleep duration, increased intake of carbohydrates and fats, and little protein ${ }^{20}$. 
Sleep duration was associated with increased body fat, waist circumference, and BMI in graduate nursing students, and the author warns of overweight and obesity ${ }^{21}$.

It is noteworthy that many students live alone, and the natural tendency is to consume food of quicker preparation or easy access, which is not always healthy. In addition, many reported not practicing physical exercise or doing it without regularity. The association between obesity and EDS may be indicative of inadequate quantity and quality of sleep ${ }^{22}$.

Concerning chronic non-communicable diseases, $30.53 \%$ of those assessed had some condition, among which $67.5 \%$ have EDS. Although an ordination was not carried out, the prevalence was higher than the findings of an author who distributed them among patients with diabetes (2\%), hypertension $(1 \%)$, cholesterolemia $(1 \%)$, and heart disease $(1 \%)$, justifying the results due to the low age of most participants, in which a high prevalence of these diseases is unexpected ${ }^{23}$. The other demographic and behavioral factors assessed in this study did not have significant associations with EDS.

The sleep quality of $73.28 \%$ of the students appraised over the PSQI had high scores, indicating poor quality. In this investigation, most students $(80 \%)$ who reported drinking alcohol showed reduced sleep quality. This association was statistically significant. These findings are substantiated by a study in which $20.1 \%$ of the participants who consumed alcohol had poor sleep quality ${ }^{24}$. The 
association was not established in another study since changes in sleep quality caused by alcohol usually occur long-term, even if the individual has already stopped consumption for prolonged periods ${ }^{23}$.

The excessive consumption of alcohol and the poor quality of sleep of university students has been the scope of studies for many ingest alcoholic beverages as a strategy to relieve stress and anxiety ${ }^{13,25}$. Although alcohol is seen as a sleep-inducing substance, its excessive intake is related to insufficient or reduced sleep quality $23,24,26$, which can result in drowsiness during academic activities in addition to emotional and motor impacts ${ }^{24}$.

Regarding the use of any medication that interferes with sleep, the majority (78.6\%) of consumer students had poor sleep quality. In some studies, the prevalence of consumption of sleep-inducing drugs among medical students was considered high $(11 \%)^{27}$. These are results above those found in other populations (6.9\% and $7.1 \%$ ). The authors attributed the excessive use of sedative drugs to the need for the student to replace the sleeping period with study or other activities ${ }^{27,28}$.

The time spent by students in their return home from college, as well as the need to fulfill their tasks, could delay their retreat to bed, thus leading to sleep deprivation. There was no statistically significant difference between students who spent more or less time getting home, but the majority (82.4\%) of those who took more than thirty minutes to arrive exhibited worse sleep quality. 
The anthropometric analysis of this research revealed that the studied population was healthy, an expected occurrence since most participants were aged between 1825 years, however, more than half of students with normal metabolic parameters were classified by the PSQI as having poor sleep quality.

In a study carried out with medical students with a mean age of 22 years, there was no relationship between metabolic data and sleep variables in this population. The author attributes this to the effects of poor sleep quality on the metabolic profile occurring in the long term ${ }^{24}$.

Although the media, in its most diverse modalities, draws society's attention to the importance of good sleep quality for human health, it is essential to highlight that some medical students will not be able to meet the recommendations for a healthy life, considering the number of commitments and responsibilities that they assume throughout their lives ${ }^{25}$.

Medical students become exposed to intense and varied levels of stress during their academic course since their entry into an environment different from that experienced in high school, often associated with family separation due to approval in universities far from their home, and, in the final stage, the prospect of entering the professional field ${ }^{26,29}$. These situations can generate irritability, anxiety, and, consequently, EDS and poor sleep quality ${ }^{22,23}$.

This research addressed important aspects of sleep quality and excessive daytime sleepiness and their 
connection with factors that can interfere with sleep, with likely harmful effects on the health of medical students during the academic period.

\section{CONCLUSIONS}

The present study concludes that the high prevalence of excessive daytime sleepiness found in most medical students is predominant in females and in those with noncommunicable chronic diseases. In addition, the poor sleep quality observed among the students can be associated with demographic and behavioral factors, such as drinking alcohol and medications that interfere with sleep.

The present study has several strengths, including the sample being composed of medical students who will be future health professionals. Another strength is its longitudinal design, which allows determining the action of time on the studied variables. As a limitation of the present study, there is a lack of discrimination against noncommunicable chronic diseases and medications that, when consumed by students, can interfere with sleep. The analysis carried out in this research did not make comparisons in relation to marital status, cohabitation, education, work, among other sociodemographic aspects. The physical, mental, and mental health status, as well as other possible mediators in the relationship between sleep and wakefulness, were also not examined.

Considering that these students may present risk factors for developing an irregular sleep-wake cycle, it is 
suggested to expand studies on other factors associated with excessive daytime sleepiness and poor sleep quality. A future study may contemplate other aspects related to total sleep time, sleep latency and sleep efficiency, including the consumption of other stimulant drinks, evaluating parameters such as exposure to light emitted by electronic devices (mobile phones, computers, tablets...) used by university students before bedtime.

\section{REFERENCES}

1.Carley DW, Farabi SS. Physiology of sleep. Diabetes Spectr 2016;29:5-9. http://dx.doi.org/10.2337/diaspect.29.1.5

2.Jagannath A, Taylor L, Wakaf Z, Vasudevan SR, Foster RG. The genetics of circadian rhythms, sleep and health. Hum Mol Genet 2017;26:R128-38. http://dx.doi.org/10.1093/hmg/ddx240

3.Al-Kandari S, Alsalem A, Al-Mutairi S, Al-Lumai D, Dawoud A, Moussa $M$. Association between sleep hygiene awareness and practice with sleep quality among Kuwait University students. Sleep Heal 2017;3:342-7. http://dx.doi.org/10.1016/j.sleh.2017.06.004

4.Araújo MFM, Lima ACS, Alencar AMPG, Araújo TM, Fragoso LVC, Damasceno MMC. Avaliação da qualidade do sono de estudantes universitários de Fortaleza-CE. Texto e Context Enferm 2013;22:35260. https://doi.org/10.1590/S0104-07072013000200011

5.Yang KI, Kim JH, Hwangbo Y, Koo DL, Kim D, Hwang KJ, et al. Prevalence of self-perceived snoring and apnea and their association with daytime sleepiness in Korean high school students. J Clin Neurol 2017;13:265-72. http://dx.doi.org/10.3988/icn.2017.13.3.265

6.Almojali AI, Almalki SA, Alothman AS, Masuadi EM, Alaqeel MK. The prevalence and association of stress with sleep quality among medical students. J Epidemiol Glob Health 2017;7:169-74. http://dx.doi.org/10.1016/j.jegh.2017.04.005

7.Corrêa CC, Oliveira FK, Pizzamiglio DS, Ortolan EVP, Weber SAT. Qualidade de sono em estudantes de medicina: Comparação das diferentes fases do curso. J Bras Pneumol 2017;43:285-9. http://dx.doi.org/10.1590/S1806-37562016000000178

8.Abdulah DM, Piro RS. Sleep disorders as primary and secondary factors in relation with daily functioning in medical students. Ann Saudi Med 2018;38:57-64. http://dx.doi.org/10.5144/0256-4947.2018.57 9.Al-Khani AM, Sarhandi MI, Zaghloul MS, Ewid M, Saquib N. A crosssectional survey on sleep quality, mental health, and academic performance among medical students in Saudi Arabia. BMC Res Notes 2019;12:1-5. https://doi.org/10.1186/s13104-019-4713-2 
10.Ferreira CMG, Kluthcovsky ACGC, Dornelles CF, Stumpf MAM, Cordeiro TMG. Qualidade do sono em estudantes de medicina de uma universidade do Sul do Brasil. Conex Ciência 2017;12:78-85. https://doi.org/10.24862/cco.v12i1.501

11.Ahrberg K, Dresler M, Niedermaier S, Steiger A, Genzel L. The interaction between sleep quality and academic performance. J Psychiatr Res 2012;46:1618-22.

https://doi.org/10.1016/j.jpsychires.2012.09.008

12.Silva R, Sarmento TA, Feitosa AN, Brito L. Qualidade do sono e sonolência excessiva entre estudantes de medicina. Rev Med 2020;99:350-6.

https://doi.org/10.11606/issn.1679-

9836.v99i4p350-356

13.Purim KSM, Guimarães ATB, Kapptitski AC, Leite N. Privação do sono e sonolência excessiva em médicos residentes e estudantes de medicina. Rev Col Bras Cir 2016;43:438-

44. https://doi.org/10.1590/0100-69912016006005

14. Harvard Humanitarian Initiative. Kokotoolbox (endereço na Internet). Available from: www.koboltoolbox.org

15. El Hangouche AJ, Jniene A, Aboudrar S, Errguig L, Rkain H, Cherti $M$, et al. Relationship between poor quality sleep, excessive daytime sleepiness and low academic performance in medical students. Adv Med Educ Pract 2018;9:631-8. https://doi.org/10.2147/AMEP.S162350

16.Alsaggaf MA, Wali SO, Merdad RA. Sleep quantity, quality, and insomnia symptoms of medical students during clinical years.Relationship with stress and academic performance. Saudi Med j 2016;37:173-82. https://doi.org/10.15537/smj.2016.2.14288

17. Fiedler P. Avaliação da qualidade de vida do estudante de medicina e da influência exercida pela formação acadêmica (thesis). São Paulo: Universidade de São Paulo; 2008. https://doi.org/10.11606/T.5.2008.tde-10072008-161825

18.Pacheco JPG, Giacomin HT, Tam WW, Ribeiro TB, Arab C, Bezerra IM, et al. Mental health problems among medical students in Brazil: A systematic review and meta-analysis. Rev Bras Psiquiatr. 2017;39(4):369-78. https://doi.org/10.1590/1516-4446-2017-2223 19.Huang CF, Yang LY, Wu LM, Liu Y, Chen HM. Determinants of daytime sleepiness in first-year nursing students: A questionnaire survey. Nurse Educ Today 2014;34:1048-53.

https://doi.org/10.1016/j.nedt.2013.11.005

20.Grandner MA. Sleep and obesity risk in adults: possible mechanisms; contextual factors; and implications for research, intervention, and policy. Sleep Heal 2017;3:393-400. https://doi.org/10.1016/j.sleh.2017.07.014

21.Dos A, Garcia S, Louro TQ, Santiago LC, Lyra Da Silva RC, Tereza $\mathrm{M}$, et al. Avaliação da qualidade do sono de pos graduandos de enfermagem. Rev Enferm UFPE line 2019;13:1444-53. https://doi.org/10.5205/1981-8963-v13i05a239167p1444-1453-

2019

22.Rhéaume A, Mullen J. The impact of long work hours and shift work 
on cognitive errors in nurses. J Nurs Manag 2018;26:26-32. https://doi.org/10.1111/jonm.12513

23.Durán-Agüero S, Sepúlveda R, Guerrero-Wyss M. Sleep disorders and anthropometric measures in Chilean university students. Rev Esp Nutr Humana y Diet 2019;23:153-61. https://dx.doi.org/10.14306/renhyd.23.3.646

24.Galvão A, Pinheiro M, Gomes MJ, Ala S. Ansiedade, stress e depressão relacionados com perturbações do sono-vigília e consumo de álcool em alunos do ensino superior. Rev Port Enferm Saúde Ment 2017;5:8-12. https://hdl.handle.net/10198/16982

25. Ribeiro SS, Ribeiro ES, Santos JC, Brito GP, Cardoso YM, Ramos MSN, et al. Qualidade do sono e sua associação com variáveis metabólicas em estudantes de medicina de uma instituição do Pará. Braz J Health Rev 2020;3:13325-37. https://dx.doi.org/10.34119/bjhrv3n5-158

26. Moreira HA, Souza KN, Yamaguchi MU. Síndrome de Burnout em médicos: uma revisão sistemática. Rev Bras Saúde Ocup 2018;43:11. https://doi.org/10.1590/2317-6369000013316

27.Zarghami M, Khalilian A, Setareh J, Salehpour G. The Impact of Using Cell Phones After Light-Out on Sleep Quality, Headache, Tiredness, and Distractibility Among Students of a University in North of Iran. Iran J psychiatry Behav Sci 2015;9:e2010. https://dx.doi.org/10.17795/ijpbs-2010

28. Korsiak J, Tranmer J, Leung M, Borghese MM, Aronson KJ. Actigraph measures of sleep among female hospital employees working day or alternating day and night shifts. J Sleep Res 2018;27:1-8. https://dx.doi.org/10.1111/jsr.12579

29.Choueiry N, Salamoun T, Jabbour H, El Osta N, Hajj A, Rabbaa Khabbaz L. Insomnia and Relationship with Anxiety in University Students: A Cross-Sectional Designed Study. PLoS One 2016;11:e0149643.

https://dx.doi.org/10.1371/journal. pone.0149643 